\title{
Indoor air quality in Michigan schools
}

\begin{abstract}
Indoor air quality (IAQ) parameters in 64 elementary and middle school classrooms in Michigan were examined for the purposes of assessing ventilation rates, levels of volatile organic compounds (VOCs) and bioaerosols, air quality differences within and between schools, and emission sources. In each classroom, bioaerosols, VOCs, $\mathrm{CO}_{2}$, relative humidity, and temperature were monitored over one workweek, and a comprehensive walkthough survey was completed. Ventilation rates were derived from $\mathrm{CO}_{2}$ and occupancy data. Ventilation was poor in many of the tested classrooms, e.g., $\mathrm{CO}_{2}$ concentrations often exceeded $1000 \mathrm{ppm}$ and sometimes $3000 \mathrm{ppm}$. Most VOCs had low concentrations (mean of individual species $<4.5 \mu \mathrm{g} / \mathrm{m}^{3}$ ); bioaerosol concentrations were moderate ( $<6500$ count per $\mathrm{m}^{3}$ indoors, $<41,000$ count per $\mathrm{m}^{3}$ outdoors). The variability of $\mathrm{CO}_{2}$, VOC, and bioaerosol concentrations within schools exceeded the variability between schools. These findings suggest that none of the sampled rooms were contaminated and that no building-wide contamination sources were present. However, localized IAQ problems might remain in spaces where contaminant sources are concentrated and that are poorly ventilated.
\end{abstract}

\section{Godwin, S. Batterman}

University of Michigan, Ann Arbor, MI, USA

Key words: Indoor air quality; Schools; Volatile organic compounds; Bioaerosols; Ventilation; Exposure assessment.

S. Batterman

Environmental Health Sciences, 1420 Washington Heights, Ann Arbor, MI 48109-2029, USA.

Tel.: 734/763-2417

e-mail: StuartB@umich.edu

Received for review 17 February 2006

Accepted for publication 15 July 2006

(C) Indoor Air (2006)

\section{Practical Implications}

Indoor air quality (IAQ) is a continuing concern for students, parents, teachers, and school staff, leading to many complaints regarding poor IAQ. Investigations of these complaints often include air sampling, which must be carefully conducted if representative data are to be collected. To better understand sampling results, investigators need to account for the variability of contaminants both within and between schools.

\section{Introduction}

Primary and secondary education is the largest public enterprise in the United States, employing over 3 million teachers and staff who instruct over 47 million children in 92,012 elementary, middle and high schools in 15,000 districts (GAO, 1995; NCES, 2002). Despite this large population, concerns regarding poor indoor air quality (IAQ), and evidence that building systems in half of the US schools have significant defects that may degrade IAQ, systematic assessments of IAQ and health and comfort issues have been rarely undertaken in schools. Consequently, the understanding of exposures and the association of symptoms and health effects remain incomplete. Pollutant emissions can occur in many school settings, e.g., cafeterias, wood shops, gyms, swimming pools, science labs (often without fume hoods), arts and crafts, and computer rooms. IAQ problems may be exacerbated in schools owing to the potential sensitivity of occupants, the simple and inexpensive building construction at most schools (commonly slab-on-grade construction with flat roofs), minimal landscaping with poor drainage, basic and minimally engineered heating, ventilation, and air conditioning HVAC units (typically wall or roof-mounted unitary systems with fixed and constant flows and exchange), the lack of preventative maintenance, and crowded conditions.

Many investigations examining IAQ problems in US schools have been complaint-driven in response to specific concerns or worker compensation issues, while in some European and other industrialized nations investigations have been driven by legislative initiatives or building standards. Often a specific pollutant, e.g., radon, asbestos or bioaerosols, or combination of pollutants are addressed (GAO, 1995). In the United States, almost half of the US schools were estimated to have one or more building defects, with HVAC systems being the most common building feature in need of repair (GAO, 1996). A review of the literature examining European schools found similar conditions (Carrer et al., 2002). Microbial and chemical exposures related to indoor sources and building characteristics found in schools, e.g., excessive dampness and poor ventilation, have been linked to reduced school attendance, respiratory infections, asthma, and allergy in children and adults (Mendell and Heath, 2004). Another recent review found that although levels of 


\section{Godwin \& Batterman}

the pollutants most commonly measured (formaldehyde, total volatile organic compounds, bioaerosols) were generally below workplace standards and guidelines, pollutant exposures were sufficiently high and were found to be associated with allergy, asthma, and other respiratory symptoms (Daisey et al., 2003).

The goals of this paper are to characterize selected IAQ parameters in a mid-size school district, assess the variability in pollutant levels between and within schools, and to link pollutants to classroom activities, ventilation rates, and other factors.

\section{Methods}

School and room selection

We randomly selected four elementary schools and all five middle schools in a suburban school district in southeast Michigan that had a total of 21 elementary schools, 5 middle schools, 3 high schools, and over 1200 teachers and staff. High schools were excluded in part owing to their size and dissimilarity with other buildings. Within each school, at least one art room, one miscellaneous use room (e.g., music, library), two general classrooms, two science rooms (in middle schools), and two office/clerical rooms were selected at random from the pool of candidate rooms. The selected buildings were diverse, ranging from 31 to 81 years of age. Several schools had fixed (unopenable) windows, and two were equipped with air conditioning (Table 1). All schools had mechanical ventilation and none used displacement ventilation (Table 1). Middle schools were slightly newer, one had air conditioning, and all had openable windows. Five to eight classrooms in each school were simultaneously studied for a period of 1 week in spring and early summer (March 31 to June 7, 2003). Rooms were selected randomly among candidate types and included general, science, music and art classrooms, offices, media/computer centers, and so on. Three portable classrooms (self-contained, prefabricated, free-standing buildings) were studied at one middle school. Participant recruitment, consenting, and other procedures were approved by the Institutional Review Board at the University of Michigan.

\section{IAQ sampling and analysis}

Sampling included volatile organic compounds (VOCs), bioaerosols, temperature, relative humidity $(\mathrm{RH})$, and $\mathrm{CO}_{2}$ in each room, and VOCs, bioaerosols, temperature, and RH outdoors. Monitoring was conducted in occupied rooms over a 4.5-day period in most schools (3.5 days in schools 3 and 8 owing to holidays). We attempted to place samplers in representative locations that were secure from tampering, at least $0.6 \mathrm{~m}$ above the floor and below the ceiling, away from windows, doors, and obvious sources of potential contaminants (kilns, animal enclosures, and the like), at least $0.5 \mathrm{~m}$ away from bookshelves and other potentially stagnant areas, and out of reach of children. Simultaneous outdoor air samples were taken at rooftop locations at each school, in a sheltered location out of direct sunlight and away from stacks, vents, and so on.

VOC samples were collected passively onto thermally desorbed adsorbents (Tenax GR) using a validated method (Batterman et al., 2002; Peng and Batterman, 2000). Collected samples and quality assurance samples (blanks and spiked samples) were analyzed for over 80 compounds within several days of collection using an automated short-path thermal desorption/cryofocusing system (Model 2000; Scientific Instrument Services, Ringoes, NJ, USA) and a gas chromatograph/mass spectrometer operating in scan mode (GC/MS, Model 6890/5973 running Chemstation, G1701BA, Version B.01, Hewlett-Packard, Palo Alto, CA, USA). The sampling volume was temperature-adjusted. Laboratory and field blanks, collected in each school, showed concentrations below method detection limits (MDLs) in all cases. All samples were collected in duplicate, and replicate precision for measurements $\geq 1 \mu \mathrm{g} / \mathrm{m}^{3}$ was better than $15 \%$, therefore averages of replicates were used in all reported analyses. Nondetects were set to one-half of the MDL $\left(\sim 0.02 \mu \mathrm{g} / \mathrm{m}^{3}\right.$ for most compounds). The total VOC (TVOC) concentration, defined here as the sum of both target and nontarget peaks (excluding hexane) normalized to toluene equivalents, was determined for each sample.

Temperature, $\mathrm{RH}$, and $\mathrm{CO}_{2}$ were measured every 5 min using integrated data loggers (Hobo HO-8; Onset Computer Corporation, Bourne, MA, USA), which were calibrated at four temperatures and two humidities (using $\mathrm{MgCl}$ and $\mathrm{NaCl}$ saturated salt solutions for $33 \%$ and $72 \% \mathrm{RH}$, respectively). $\mathrm{CO}_{2}$ sensors (GMW-20; Vaisala Corporation, Helsinki, Finland) were calibrated using pure nitrogen and a 1011-ppm $\mathrm{CO}_{2}$ standard. $\mathrm{CO}_{2}$ data were lost in 17 rooms owing to equipment problems or tampering; data are complete for 47 rooms. Bioaerosol and particle concentrations were measured using 5-min (indoor) or 10-min (outdoor) sampling periods and filter cassette sampling systems (Air-O-Cell; SKC Corp., Eighty-four, PA, USA). Speciated spore counts, pollen, fibers, insect and skin fragments were optically determined by a certified laboratory. Bioaerosol levels were reported as counts per $\mathrm{m}^{3}$ (includes both viable and nonviable spores), and particle concentrations as 'total background particle density'. Blanks taken at each school were negative.

\section{Visual inspections}

A walkthrough inspection and checklist was completed for each school to document HVAC system operation and hygiene, air intake location, sources of 


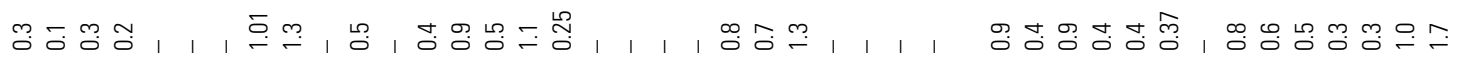
营-

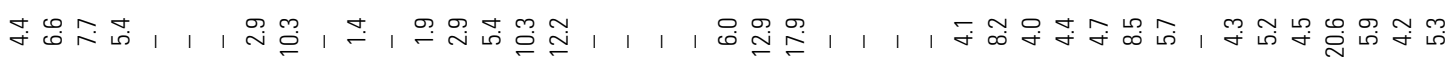

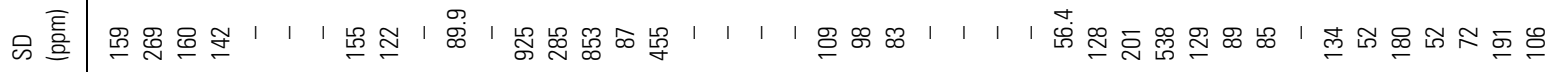
悉言

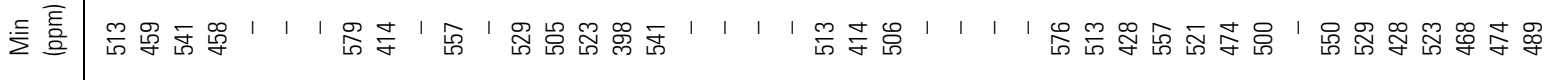

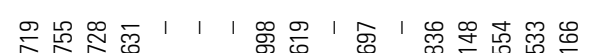

1 1 1 2

o

폴

伭

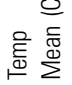

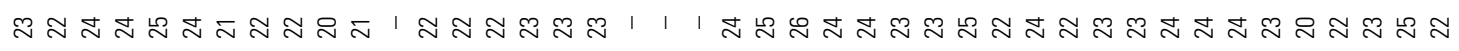
마

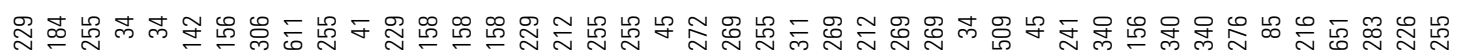

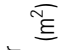

か

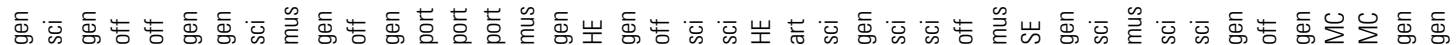
छิ

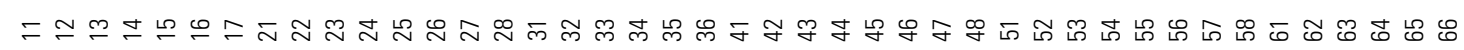

$\stackrel{\bar{\xi}}{\underset{y}{\ddagger}}$

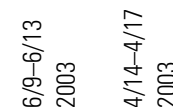

点

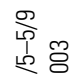

$\stackrel{0}{\frac{6}{10}}$ 


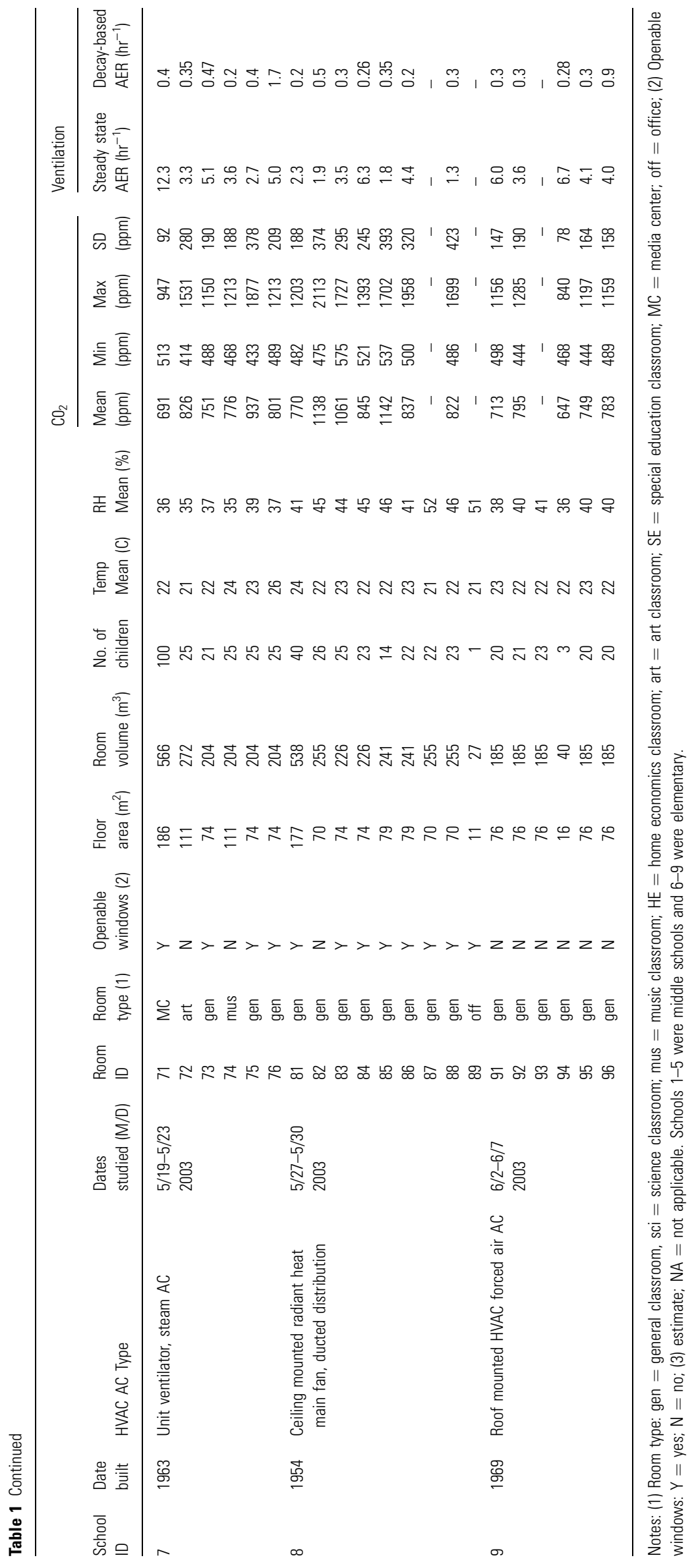


contaminants, building drainage, roof, attic and interior inspection, maintenance, combustion appliances, room area and volume, carpets, animals, special facilities, space usage, and other factors. Photos of each room were taken. Floor plans and other information regarding the school were obtained.

\section{Air exchange rates}

Using $\mathrm{CO}_{2}$ as a tracer, air exchange rates (AER) were estimated using two methods. The 'steady-state' AER $_{\mathrm{ss}}$ $\left(\mathrm{h}^{-1}\right)$ was calculated as

$$
\mathrm{AER}_{\mathrm{ss}}=n S /\left[V\left(C_{\max }-C_{\min }\right)\right]
$$

where $n$ is the number of persons in the room; $S$ is the $\mathrm{CO}_{2}$ emission rate per person, taken as $0.31 \mathrm{~min}$ per person (ASHRAE 62-2001, 2001); $V$ is the room volume estimated from floor dimensions and room height; $C_{\max }$ is the maximum sustained indoor $\mathrm{CO}_{2}$ concentration; and $C_{\min }$ is the estimated minimum concentration. $C_{\max }$ was generally taken as a 2 -h average mid-day concentration ( 11:00 to 13:00), and $C_{\text {min }}$ was the lowest concentration observed during the monitoring period. Because ventilation was turned off in the late afternoon, $\mathrm{CO}_{2}$ levels generally did not fall to outdoor levels $(\sim 370 \mathrm{ppm})$, but remained slightly elevated (420$450 \mathrm{ppm}) . \mathrm{AER}_{\mathrm{ss}}$ was determined for each study day by examining the trendline of the $\mathrm{CO}_{2}$ concentration to select time periods when steady state was achieved; an average of 3-5 days is reported. AER $\mathrm{As}_{\mathrm{ss}}$ is a mid-day measurement obtained when ventilation systems were fully operating and after $\mathrm{CO}_{2}$ levels had stabilized, and relatively high rates were expected.

The second AER estimate fitted the decay in $\mathrm{CO}_{2}$ levels measured at the end of the school day to a firstorder model:

$$
C_{t}=C_{0} \exp \left(-A E R_{\mathrm{DECAY}} t\right)+C_{\min }
$$

where $C_{t}$ is the observed $\mathrm{CO}_{2}$ concentration at time $t$; $C_{0}$ is the estimated initial concentration; $\mathrm{AER}_{\mathrm{DECAY}}$ is the estimated decay rate; and $C_{\min }$ is the minimum concentration. Parameters were estimated by regressing the logarithm of concentrations against time using the afternoon period just after children left the room (typically 14:30 to 16:30). AER DECAY $_{\text {was determined }}$ for each study day, and the reported value is averaged over 3-5 days. Most AER DECAY estimates were robust, i.e., regressions achieved high $R^{2}$ and the dayto-day variation was small. AER ${ }_{\text {DECAY }}$ represents the period immediately following occupancy, often when ventilation systems were turned off and windows were closed, thus low rates were expected.

\section{Statistical analysis}

For VOCs, detection probabilities (fraction of observations above LODs) were calculated. VOC distribu- tions were asymmetric and non-normal, therefore, log-transformations were used in hypothesis testing, and Spearman rank correlations were used (Zar, 1999). Only VOCs with detection probabilities $>50 \%$ were selected for correlations, scatter plots, ANOVA, factor analyses, and multiple linear regression. Differences in average concentrations between middle and elementary schools were tested using Student's $t$ and MannWhitney tests. To control for intraclass correlations for elementary and middle schools and for the dependencies of measurements taken in a given school building, within- and between-school variability was evaluated using mixed linear models. The significance of between-school variability was determined using log likelihood ratio tests (Verbeke and Molenberghs, 2000). Excel, Access (Microsoft, Seattle, WA), SAS v. 9 (SAS Institute, Cary, NC, USA), and Systat v.10 (SPSS Corporation, Chicago IL, USA) were used to manage data, provide QA/QC checks, and generate statistics.

Linear regression models were used to assess effects of building environmental factors on measured concentrations of selected indoor air contaminants, specifically, VOCs and bioaerosols that had detection probabilities exceeding 50\%. Initially, predictor variables included building factors that had statistically significant correlation coefficients with the contaminants. Subsequently, stepwise regression was used to develop multivariate models (SAS Institute).

\section{Results}

Sixty-four rooms in five middle and four elementary schools were sampled, with $47(73 \%)$ having openable windows (Table 1$)$. Nearly half ( 31 rooms, $48 \%$ ) were general classrooms of which $23(74 \%)$ had openable windows. The rest of the rooms were science $(10,16 \%)$, offices $(7,11 \%)$, music $(5,8 \%)$, or other $(11,17 \%)$ rooms.

\section{VOC concentrations, correlations, and sources}

The most prevalent VOCs in schools were benzene, ethylbenzene, toluene, xylene, $\alpha$-pinene, and limonene, and, as expected, indoor concentrations usually exceeded outdoor levels (Table 2, Figure 1). Target compounds constituted $36 \pm 19 \%$ of TVOC in the 50 permanent classrooms, and $34 \pm 12 \%$ of TVOC in the three portable classrooms. With the exception of $\alpha$ pinene and limonene, VOC levels were lower than levels reported previously in schools (e.g., Shendell et al., 2004a). TVOC levels also were comparable or lower than that found in the other studies. Concentrations of limonene, $\alpha$-pinene, toluene, and $m, p$-xylene across the 64 rooms were significantly correlated $(r=$ $0.30-0.56$ ) with TVOC (Table 3 ). In contrast, benzene was negatively, but not significantly, correlated with most other VOCs except naphthalene $(r=0.22)$; 


\section{Godwin \& Batterman}

Table 2 Summary statistics of volatile organic compounds (VOC) and bioaerosol concentrations in schools and outdoors

\begin{tabular}{|c|c|c|c|c|c|c|c|c|}
\hline \multirow[b]{2}{*}{ VOCs } & \multicolumn{4}{|l|}{ Classrooms } & \multicolumn{4}{|l|}{ Outdoors } \\
\hline & Mean $\left(\mu \mathrm{g} / \mathrm{m}^{3}\right)$ & 90th $\left(\mu \mathrm{g} / \mathrm{m}^{3}\right)$ & $\operatorname{Max}\left(\mu \mathrm{g} / \mathrm{m}^{3}\right)$ & Det. Freq $(\%)$ & Mean $\left(\mu \mathrm{g} / \mathrm{m}^{3}\right)$ & 90th $\left(\mu \mathrm{g} / \mathrm{m}^{3}\right)$ & $\operatorname{Max}\left(\mu \mathrm{g} / \mathrm{m}^{3}\right)$ & Det. freq $(\%)$ \\
\hline \multicolumn{9}{|l|}{ Aromatics } \\
\hline Benzene & 0.09 & 0.2 & 1.6 & 62 & 0.06 & 0.1 & 0.1 & 70 \\
\hline Ethylbenzene & 0.24 & 0.7 & 2.8 & 37 & $<0.01$ & 0.0 & 0.0 & 0 \\
\hline Toluene & 2.81 & 3.6 & 74.6 & 100 & 0.52 & 1.0 & 1.0 & 90 \\
\hline$p, m$-Xylene 0.83 & 2.3 & 10.2 & 63 & 0.03 & 0.0 & 0.2 & 10 & \\
\hline o-Xylene & 0.24 & 0.6 & 3.8 & 32 & $<0.01$ & 0.0 & 0.0 & 0 \\
\hline Styrene & 0.04 & 0.0 & 1.4 & 23 & $<0.01$ & 0.0 & 0.0 & 0 \\
\hline 1,3,5-Trimethylbenzene & 0.02 & 0.0 & 0.2 & 11 & $<0.01$ & 0.0 & 0.0 & 0 \\
\hline 1,2,4-Trimethylbenzene & 0.14 & 0.4 & 1.5 & 51 & 0.01 & 0.0 & 0.0 & 10 \\
\hline$p$-Isopropyltoluene & 0.02 & 0.0 & 0.6 & 6 & $<0.01$ & 0.0 & 0.0 & 0 \\
\hline Chlorinated & & & & & $<0.01$ & & & \\
\hline 1,3-Dichlorobenzene & 0.02 & 0.0 & 0.4 & 2 & $<0.01$ & 0.0 & 0.0 & 0 \\
\hline 1.2.3-Trichlorobenzene & 0.01 & 0.0 & 0.3 & 2 & $<0.01$ & 0.0 & 0.0 & 0 \\
\hline 1.2.4-Trichlorobenzene & 0.07 & 0.0 & 3.9 & 2 & $<0.01$ & 0.0 & 0.0 & 0 \\
\hline Chloroform & 0.09 & 0.1 & 2.5 & 15 & $<0.01$ & 0.0 & 0.0 & 0 \\
\hline Trichloroethylene & 0.02 & 0.0 & 0.3 & 3 & 0.01 & 0.0 & 0.1 & 10 \\
\hline Tetrachloroethylene & 0.02 & 0.0 & 0.3 & 2 & $<0.01$ & 0.0 & 0.0 & 0 \\
\hline 1,2,3-Trichloropropane & 0.01 & 0.0 & 0.1 & 2 & $<0.01$ & 0.0 & 0.0 & 0 \\
\hline Other & & & & & $<0.01$ & & & \\
\hline 2-Butanone & 0.24 & 0.9 & 3.0 & 38 & $<0.01$ & 0.0 & 0.0 & 0 \\
\hline Tetrahydrofuran & 0.16 & 0.0 & 3.8 & 8 & $<0.01$ & 0.0 & 0.0 & 0 \\
\hline Methyl isobutyl ketone & 0.46 & 1.0 & 8.2 & 40 & 0.02 & 0.0 & 0.1 & 10 \\
\hline Phenol & 0.61 & 1.5 & 12.1 & 37 & 0.13 & 0.1 & 1.2 & 10 \\
\hline$\alpha$-Pinene & 1.35 & 1.9 & 35.2 & 72 & 0.11 & 0.5 & 0.6 & 20 \\
\hline Limonene & 4.41 & 8.2 & 45.1 & 100 & 0.29 & 1.2 & 1.6 & 20 \\
\hline Naphthalene & 0.82 & 1.8 & 10.3 & 42 & 0.10 & 0.1 & 0.9 & 10 \\
\hline \multirow[t]{2}{*}{ Total VOCs } & 58.0 & 84.9 & 384.2 & & 10.44 & 15.1 & 27.5 & \\
\hline & \multicolumn{4}{|l|}{ Classrooms } & \multicolumn{4}{|l|}{ Outdoors } \\
\hline Bioaerosols & Median $\left(\mathrm{CFU} / \mathrm{m}^{3}\right)$ & 90th $\left(\mathrm{CFU} / \mathrm{m}^{3}\right)$ & $\operatorname{Max}\left(\mathrm{CFU} / \mathrm{m}^{3}\right)$ & Det. Freq. $(\%)$ & Median. (CFU/m $\left.\mathrm{m}^{3}\right)$ & 90th $\left(\mathrm{CFU} / \mathrm{m}^{3}\right)$ & $\operatorname{Max}\left(\mathrm{CFU} / \mathrm{m}^{3}\right)$ & Det. Freq $(\%)$ \\
\hline \multicolumn{9}{|l|}{ Mold spores } \\
\hline Agrocvbe/Coprinus & 0 & 0 & 0 & 0 & 0 & 254 & 726 & 30 \\
\hline Alternaria & 0 & 0 & 75 & 4 & 0 & 89 & 161 & 30 \\
\hline Aspergillus/Penicillium & 484 & 1735 & 6370 & 98 & 868 & 1992 & 2820 & 100 \\
\hline Bipolaris & 0 & 81 & 403 & 13 & 61 & 484 & 484 & 50 \\
\hline Cladosporium & 0 & 121 & 726 & 27 & 484 & 13610 & 37100 & 90 \\
\hline Immature/unidentified & 0 & 81 & 161 & 18 & 20 & 141 & 323 & 50 \\
\hline Hyphae & 0 & 0 & 81 & 2 & & 00 & 0 & 0 \\
\hline Total mold spores & 505 & 1937 & 6370 & 98 & 2461 & 15879 & 40894 & 100 \\
\hline \multicolumn{9}{|l|}{ Other } \\
\hline Pollen & 0 & 0 & 75 & 4 & 0 & 173 & 282 & 20 \\
\hline Fiberglass & 0 & 0 & 38 & 2 & 0 & 8 & 81 & 10 \\
\hline Insect fragments 0 & 0 & & 38 & 4 & 0 & 0 & 0 & 0 \\
\hline
\end{tabular}

Note: For VOC, $n=65$ indoors and 10 outdoors; for bioaerosols, $n=56$ indoors and 10 outdoors.

however, benzene levels were very low (average $\left.<0.1 \mu \mathrm{g} / \mathrm{m}^{3}\right)$. Outdoor concentrations of VOCs were low (generally $<1 \mu \mathrm{g} / \mathrm{m}^{3}$ for individual compounds), reflecting the residential and suburban areas sampled. None of the schools were close to highways, and the community is largely free of strong industrial sources.

The high indoor/outdoor ratios $(\mathrm{I} / \mathrm{O}>10)$ for ethylbenzene, xylene, 2-butanone, methyl isooctane, $\alpha$-pinene, and limonene, and the moderate $\mathrm{I} / \mathrm{O}$ ratios ( $>4$ ) for toluene, styrene, 1,2,4-trichlorobenzene, chloroform, phenol, and naphthalene suggest indoor sources for these VOCs. In contrast, the $\mathrm{I} / \mathrm{O}$ ratio for benzene (1.4), indicates that outdoor sources were the primary contributors.

Each middle school showed traces of chloroform, trichloroethylene and 1,2,3-trichlorobenzene (mean < $0.1 \mu \mathrm{g} / \mathrm{m}^{3}$, maximum $<4 \mu \mathrm{g} / \mathrm{m}^{3}$ ), and each had an indoor swimming pool. Additional sampling at three locations in the distribution ducts of the ventilation system of one of the middle schools showed that the pools were a chloroform source, likely a by-product of chlorine disinfection. These compounds were rarely detected in the elementary schools, which did not have pools. A primary school art room (room 72) had the highest concentrations of toluene, methyl isobutyl 

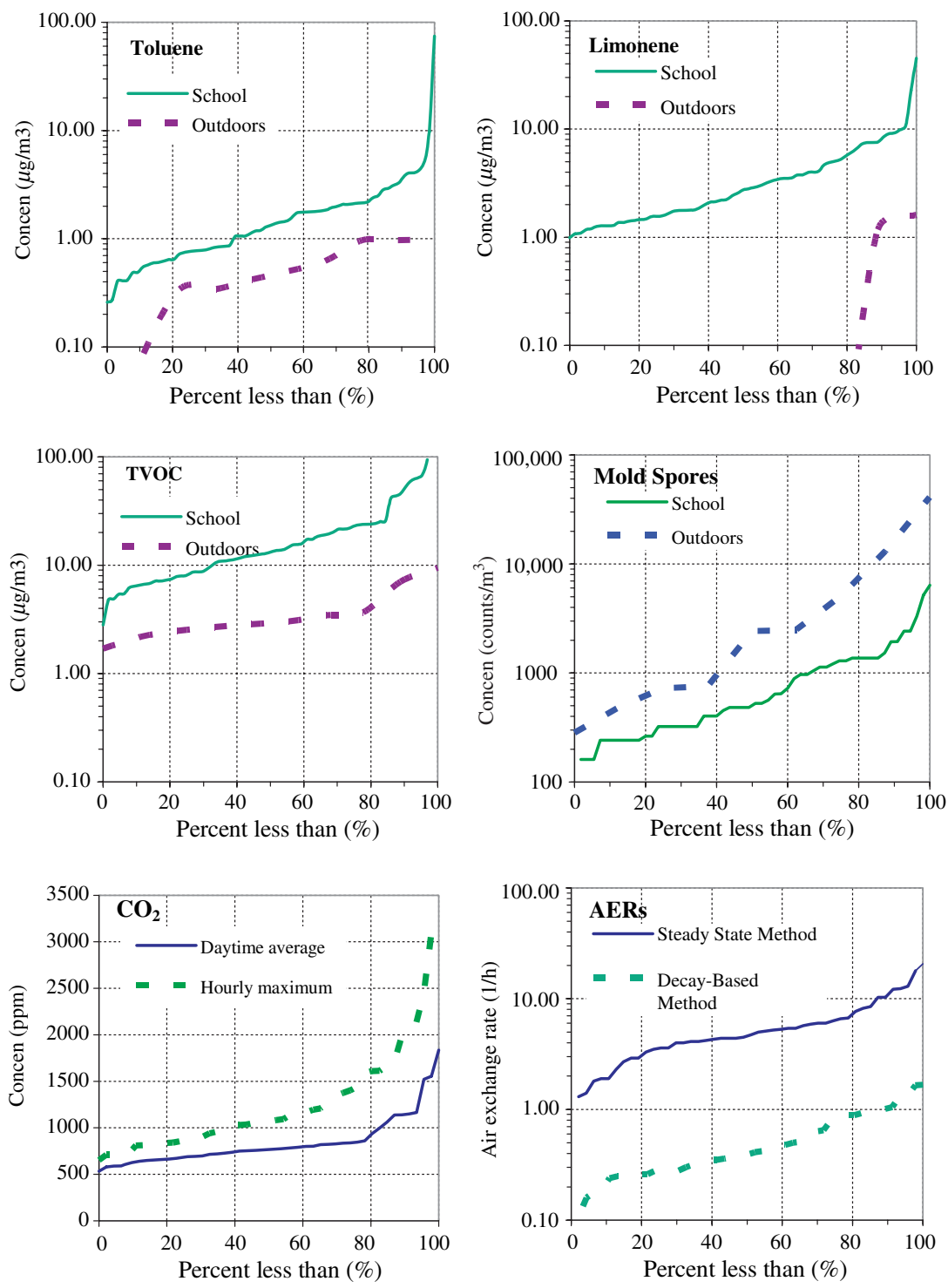

Fig. 1 Distributions of toluene, limonene, benzene, total volatile organic compound concentrations in 65 school rooms and 10 outside locations; total mold spore concentration in 56 school rooms and nine outdoors; maximum and average $\mathrm{CO}_{2}$ in 47 school rooms; and air exchange rates in 47 and 48 rooms for steady-state and decay-based methods, respectively

ketone, and phenol $\left(9.8,8.2\right.$, and $12 \mu \mathrm{g} / \mathrm{m}^{3}$, respectively), while a middle school art room (room 43) had high levels of chlorinated VOCs (chloroform and 1,2,4trichlorobenzene at 2.5 and $3.9 \mu \mathrm{g} / \mathrm{m}^{3}$, respectively). This room was close to the pool, the likely chloroform source. Science rooms showed the highest concentration of naphthalene $\left(10 \mu \mathrm{g} / \mathrm{m}^{3}\right.$ in room 56 , and $7.3 \mu \mathrm{g} /$ $\mathrm{m}^{3}$ in room 21); another science room had high levels of $\alpha$-pinene ( $35 \mu \mathrm{g} / \mathrm{m}^{3}$ in room 44$)$, a component used in many cleaning products. Levels of other VOCs in science rooms were typical. One of the three portables (room 26) tested had the highest levels of styrene and limonene (1.4 and $45 \mu \mathrm{g} / \mathrm{m}^{3}$, respectively), and the second highest levels of $\alpha$-pinene $\left(5 \mu \mathrm{g} / \mathrm{m}^{3}\right)$. Compared with conventional classrooms, portables also had higher levels of styrene ( 0.54 vs. $\left.0.02 \mu \mathrm{g} / \mathrm{m}^{3}\right), \alpha$-pinene $\left(2.6\right.$ vs. $\left.1.4 \mu \mathrm{g} / \mathrm{m}^{3}\right)$, and limonene (16.9 vs. $\left.4.0 \mu \mathrm{g} / \mathrm{m}^{3}\right)$, but lower levels of $m, p$-xylene $\left(0.15\right.$ vs. $\left.0.85 \mu \mathrm{g} / \mathrm{m}^{3}\right)$. While levels of most VOCs appear to be higher in portable classrooms, this result should be interpreted cautiously as only three portables at one school were sampled.

The multiple regression models showed that daytime average $\mathrm{CO}_{2}, \mathrm{AER}_{\mathrm{SS}}$ (i.e., daytime ventilation rate) and floor type (i.e., tile, tile/carpet, and fully carpeted) were statistically significant predictors of toluene, $m, p$ xylene, $\alpha$-pinene, limonene, and TVOC concentrations. For toluene, daytime average $\mathrm{CO}_{2}$ had a standardized coefficient (STB) of 0.27 but the adjusted multiple coefficient of determination was very small $\left(R^{2}=\right.$ $0.04)$. For $m, p$-xylene, $\mathrm{AER}_{\mathrm{SS}}(\mathrm{STB}=-0.35)$ and carpeting (STB $=-0.34)$ made significant contributions $\left(R^{2}=0.21\right)$. Similar results were obtained for $\alpha$ pinene with $\mathrm{AER}_{\mathrm{SS}}(\mathrm{STB}=-0.35)$ and carpeting 


\section{Godwin \& Batterman}

Table 3 Spearman rank correlation coefficients for frequently detected (>50\%) indoor volatile organic compounds (VOC) and bioaerosols, $\mathrm{CO}_{2}$, ventilation rates, and $s c h o o l$ room factors

\begin{tabular}{|c|c|c|c|c|c|c|c|c|c|c|c|c|c|c|c|c|}
\hline & Benzene & Toluene & $\begin{array}{l}m- \\
p \text {-xylene }\end{array}$ & $\alpha$-Pinene & Limonene & $\begin{array}{l}\text { Total } \\
\text { VOCs }\end{array}$ & Aspergillus & $\begin{array}{l}\text { Total } \\
\text { bioaerosols }\end{array}$ & $\begin{array}{l}\text { Openable } \\
\text { windows }\end{array}$ & Carpeting & $\begin{array}{l}\text { Steady } \\
\text { state } \\
\text { AER }\end{array}$ & $\begin{array}{l}\text { Weighted } \\
\text { mean } \\
\text { AER }\end{array}$ & $\begin{array}{l}\text { Decay- } \\
\text { based } \\
\text { AER }\end{array}$ & $\begin{array}{l}\text { Schoolday } \\
\text { avg. } \mathrm{CO}_{2}\end{array}$ & $\begin{array}{l}\text { Daytime } \\
\text { hourly } \\
\text { max. } \mathrm{CO}_{2}\end{array}$ & $\begin{array}{l}\text { No. } \\
\text { of } \\
\text { occupants }\end{array}$ \\
\hline Benzene & 1 & & & & & & & & & & & & & & & \\
\hline Toluene & -0.06 & 1 & & & & & & & & & & & & & & \\
\hline$m$-, $p$-xylene & -0.13 & $0.38^{*}$ & 1 & & & & & & & & & & & & & \\
\hline$\alpha$-Pinene & $-0.30^{*}$ & 0.15 & $0.45^{*}$ & 1 & & & & & & & & & & & & \\
\hline Limonene & -0.21 & $0.32^{*}$ & $0.27^{*}$ & $0.36^{*}$ & 1 & & & & & & & & & & & \\
\hline Total VOCs & $-0.29^{*}$ & $0.56^{*}$ & 0.20 & $0.30^{*}$ & $0.37^{*}$ & 1 & & & & & & & & & & \\
\hline Aspergillus & 0.13 & 0.02 & $-0.30^{*}$ & $-0.40^{*}$ & 0.07 & 0.00 & 1 & & & & & & & & & \\
\hline Total bioaerosols & 0.13 & 0.09 & -0.27 & $-0.39^{*}$ & 0.11 & -0.02 & $0.97^{*}$ & 1 & & & & & & & & \\
\hline Openable windows & 0.07 & 0.15 & $-0.29 *$ & 0.02 & -0.18 & 0.09 & -0.03 & 0.03 & 1 & & & & & & & \\
\hline Carpeting & -0.21 & 0.16 & -0.08 & -0.13 & 0.06 & 0.01 & $0.46^{*}$ & $0.45^{*}$ & 0.16 & 1 & & & & & & \\
\hline Steady state AER & 0.16 & -0.27 & $-0.40^{*}$ & $-0.37^{*}$ & $-0.42^{*}$ & $-0.30^{*}$ & -0.05 & -0.03 & 0.07 & 0.07 & 1 & & & & & \\
\hline Weighted mean AER & 0.12 & $-0.31^{*}$ & $-0.47^{*}$ & $-0.41^{*}$ & $-0.47^{*}$ & $-0.33^{*}$ & 0.07 & 0.08 & 0.15 & 0.14 & $0.94^{*}$ & 1 & & & & \\
\hline Decay-based AER & 0.08 & $-0.30^{*}$ & $-0.42^{*}$ & -0.19 & $-0.33^{*}$ & -0.19 & $0.40^{*}$ & $0.34^{*}$ & 0.22 & 0.26 & 0.14 & $0.38^{*}$ & 1 & & & \\
\hline Schoolday avg. $\mathrm{CO}_{2}$ & -0.06 & $0.45^{*}$ & 0.28 & $0.32^{*}$ & $0.42^{*}$ & $0.55^{*}$ & $\quad 0.02$ & 0.00 & 0.14 & 0.01 & $-0.56^{*}$ & $-0.48^{*}$ & -0.18 & 1 & & \\
\hline $\begin{array}{l}\text { Daytime hourly } \\
\text { max. } \mathrm{CO}_{2}\end{array}$ & 0.08 & $0.50^{*}$ & 0.30 & 0.15 & 0.30 & $0.47^{*}$ & 0.13 & 0.12 & 0.09 & 0.00 & $-0.50^{*}$ & $-0.50^{*}$ & $-0.38^{*}$ & $0.82^{*}$ & 1 & \\
\hline No. of occupants & 0.15 & 0.03 & -0.18 & -0.14 & $-0.30^{*}$ & 0.13 & 0.04 & -0.02 & 0.20 & 0.17 & $0.28^{*}$ & $0.31^{*}$ & 0.14 & 0.17 & 0.12 & 1 \\
\hline
\end{tabular}

*statistically significant. Notes: $n=58$ for VOC, no. of occupants and openable windows; $n=56$ for floor area/no. of occupants; $n=50$ for bioaerosols; $n=46$ for decay-based air exchange rate $\left(A E R_{D E C A Y}\right) ; n=45$ for school-day average $\mathrm{CO}_{2}$ and steady-state $\mathrm{AER}(\mathrm{AER} S \mathrm{SS}) ; n=39$ for daytime hourly max $\mathrm{CO}_{2}$.

$(\mathrm{STB}=-0.35)$, which gave a slightly higher fit $\left(R^{2}=\right.$ $0.26)$. Limonene was predicted using daytime average $\mathrm{CO}_{2}(\mathrm{STB}=0.33)$ and $\mathrm{AER}_{\mathrm{SS}}(\mathrm{STB}=-0.31)$ with a comparable fit $\left(R^{2}=0.29\right)$. A single variable, daytime average $\mathrm{CO}_{2}(\mathrm{STB}=0.58)$, provided the best fit for TVOC $\left(R^{2}=0.32\right)$.

VOC concentrations tended to differ significantly between elementary and middle schools as shown by both parametric (Student's $t$ ) and nonparametric (Mann-Whitney $U$ ) tests (Table 4). Toluene, m,pxylene, and limonene were higher in elementary

Table 4 Comparison of average indoor air concentrations between elementary and middle schools

\begin{tabular}{|c|c|c|c|c|c|c|c|c|}
\hline \multirow[b]{2}{*}{ Variable } & \multicolumn{3}{|c|}{ Elementary } & \multicolumn{3}{|c|}{ Middle } & \multicolumn{2}{|l|}{$P$ value } \\
\hline & $n$ & Mean & Median & $n$ & Mean & Median & $\begin{array}{l}\text { Student's } \\
\mathrm{t}\end{array}$ & $\begin{array}{l}\text { Mann- } \\
\text { Whitney u }\end{array}$ \\
\hline \multicolumn{9}{|l|}{ VOCs $\left(\mu \mathrm{g} / \mathrm{m}^{3}\right)$} \\
\hline Benzene & 26 & 0.03 & 0.01 & 29 & 0.15 & 0.07 & 0.00 & 0.00 \\
\hline Toluene & 26 & 2.05 & 1.79 & 29 & 1.20 & 1.04 & 0.01 & 0.02 \\
\hline$m, p$-Xylene & 26 & 1.64 & 1.20 & 29 & 0.15 & 0.02 & 0.00 & 0.00 \\
\hline$\alpha$-Pinene & 26 & 0.86 & 0.72 & 29 & 1.84 & 0.51 & 0.04 & 0.02 \\
\hline Limonene & 26 & 5.45 & 4.35 & 29 & 2.65 & 1.78 & 0.00 & 0.00 \\
\hline Naphthalene & 26 & 0.11 & 0.01 & 29 & 0.97 & 0.01 & 0.02 & 0.03 \\
\hline Sum target VOCs & 26 & 18.67 & 14.73 & 29 & 24.11 & 9.02 & 0.36 & 0.14 \\
\hline Total VOCs & 26 & 45.88 & 39.91 & 29 & 59.00 & 34.77 & 0.45 & 0.93 \\
\hline \multicolumn{9}{|c|}{ Bioaerosols (counts $/ \mathrm{m}^{3}$ ) } \\
\hline Aspergillus & 23 & 1115 & 1050 & 27 & 563 & 403 & 0.59 & 0.23 \\
\hline Cladosporidium & 23 & 21 & 0 & 27 & 73 & 0 & 0.16 & 0.18 \\
\hline $\begin{array}{l}\text { Immature/ } \\
\text { unidentifed }\end{array}$ & 23 & 14 & 0 & 27 & 18 & 0 & 0.91 & 0.87 \\
\hline Total bioaerosols & 23 & 1168 & 1050 & 27 & 6661 & 484 & 0.66 & 0.19 \\
\hline
\end{tabular}

Notes: Elementary schools: $n=26$ for volatile organic compounds (VOC), $n=23$ for bioaerosols. Middle schools: $n=29$ for VOC, $n=27$ for bioaerosols. Student's t-test used log-transformed data. $P$ values indicate significance of difference between middle and elementary school means. schools, while benzene, $\alpha$-pinene, and napthalene were higher in middle schools. Average TVOC concentrations did not differ significantly between elementary and middle schools. Mixed regression models controlling for school type showed that concentrations of $\alpha$-pinene and limonene varied more within schools (expressed as a percentage of the total variation) than between schools, while toluene and $m, p$-xylene showed the opposite trend (Table 5). For example, Figure 2 shows that limonene levels at most varied over an order of magnitude, and generally schools with higher concentrations also showed greater variability. For the summary measure TVOC, the majority $(57 \%)$ of the variation was owing to between-school variation.

Table 5 Within- and between-school variation in indoor air quality (IAQ) parameters and tests of differences using log-transformed data Note

\begin{tabular}{lllll}
\hline & & \multicolumn{2}{l}{ Percent of variation (\%) } & \\
\cline { 3 - 4 } Variable & $n$ & Within schools & Between schools & \\
\hline Toluene & 58 & 47 & 53 & 0.00 \\
m,p-Xylene & 58 & 44 & 56 & 0.00 \\
$\alpha$-Pinene & 58 & 52 & 48 & 0.00 \\
Limonene & 58 & 83 & 17 & 0.06 \\
Sum Target VOCs & 58 & 65 & 35 & 0.00 \\
Total VOCs & 58 & 43 & 57 & 0.00 \\
Aspergillus & 53 & 72 & 28 & 0.00 \\
Total bioaerosols & 53 & 78 & 22 & 0.02 \\
Daytime average $\mathrm{CO}_{2}$ & 46 & 76 & 24 & 0.03 \\
Hourly maximum $\mathrm{CO}_{2}$ & 45 & 77 & 23 & 0.03 \\
AER & 46 & 70 & 30 & 0.01 \\
AER & 47 & 69 & 31 & 0.02 \\
& & & &
\end{tabular}

$\mathrm{H}_{0}$ : no significant between-school difference. Between-school difference of all variables were statistically significant at $P \leq 0.05$ except limonene $(P=0.06)$. Benzene was not included because very low concentrations provided inadequate data for analyses. 


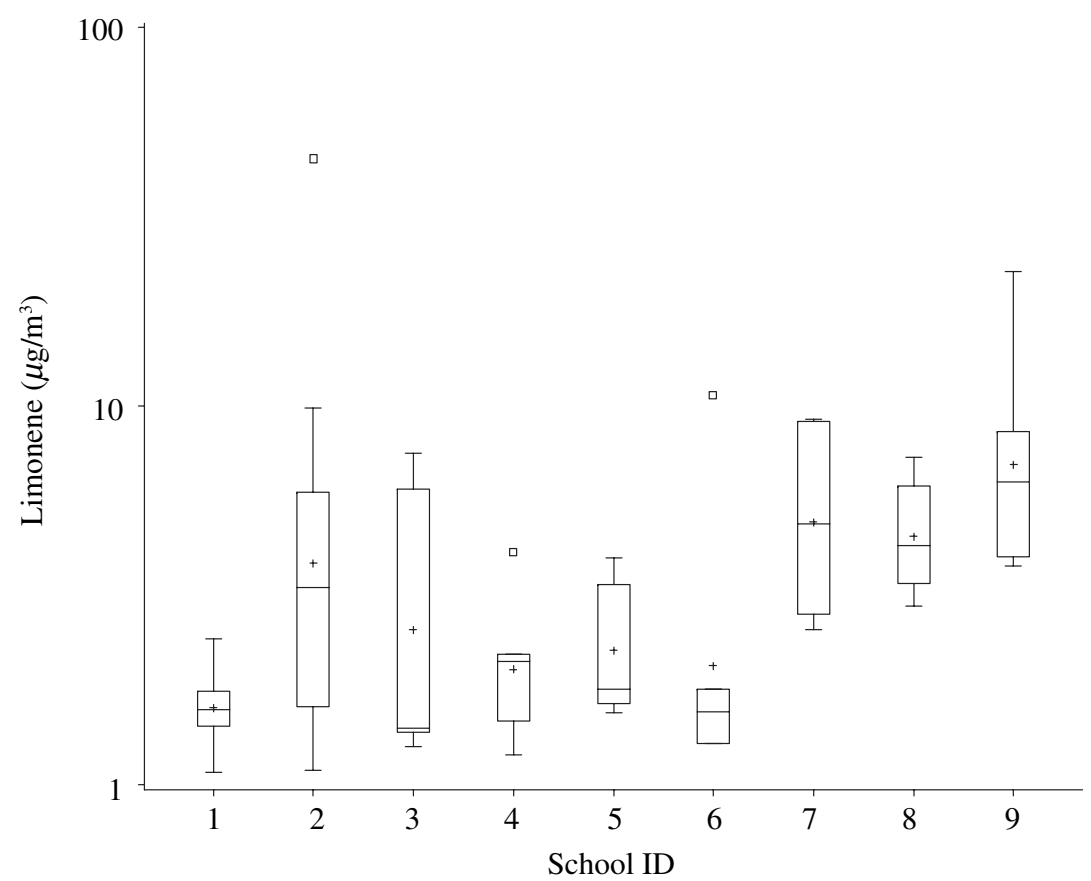

Fig. 2 Box plot of limonene concentration by school. Symbol ' $\square$ ' designates outliers, '+' identifies means. Schools $1-5$ are middle schools and 6-9 are elementary

\section{Carbon dioxide}

$\mathrm{CO}_{2}$ levels ranged widely and exceeded $1000 \mathrm{ppm}$ in at least one room at each school except school 4 (Figure 1, Table 1). Peak levels reached 2700 and $3330 \mathrm{ppm}$ in a nonportable and portable classrooms, respectively (rooms 53 and 28). High $\mathrm{CO}_{2}$ levels were found in all three portable classrooms. Maximum $\mathrm{CO}_{2}$ levels should be interpreted cautiously as they may reflect events such as occupants clustering around and/or breathing on the sensor. Average $\mathrm{CO}_{2}$ levels, which are robust as they represent school-day periods averaged over 3 or 4 days, ranged from 533 to $1522 \mathrm{ppm}$ in individual nonportable classrooms and from 1148 to 1836 in the three portables (rooms 26, 27, and 28). Both daytime average and hourly maximum $\mathrm{CO}_{2}$ levels showed much greater withinschool variability $(76-77 \%)$ than between-school variability (23-24\%, Table 5).

\section{Bioaerosols}

Five mold genera were detected in schools, of which Aspergillus/Penicillium was by far the most common and found in all indoor and outdoor samples. Cladosporium was the next most common, found in $27 \%$ of indoor samples and $90 \%$ of outdoor samples (Table 2). Mildew, Chaetimium, Curvularia, Ganoderma, Pericon$a$, and Stachybotrys were not detected. Identified genera were found both indoors and outdoors, i.e., none was present exclusively indoors or outdoors. Pollen, fiberglass, and insect fragments were detected at a few sites, especially in school 1 . The total mold spore concentrations ranged widely (Figure 1). For most species and schools, outdoor levels (median $=2461$ counts per $\mathrm{m}^{3}, n=10$ ) exceeded indoor levels (median $=527$ counts per $\left.\mathrm{m}^{3}, n=74\right)$. The exception was Aspergillus/Penicillium, for which schools 2, 3, 7, and 9 had average $\mathrm{I} / \mathrm{O}$ ratios of $3.5,3.2,6.9$, and 1.4 , respectively. I/O ratios at schools 2,3 , and 7 were affected by low outdoor levels (121 to 323 counts per $\mathrm{m}^{3}$ ); outdoor levels at school 9 were typical (928 counts per $\mathrm{m}^{3}$ ). These results suggest possible indoor sources of Aspergillus and/or Penicillium at school 9. Portable classrooms had higher bioaerosol concentrations than conventional classrooms (e.g., median levels of Aspergillus/Penicillium of 1610 vs. 443 counts per $\mathrm{m}^{3}$, respectively); however, as mentioned with regards to VOCs, this comparison is based on only three portables. A total mold spore concentration of 1000 counts per $\mathrm{m}^{3}$, sometimes used as a guideline (e.g., Bush and Portnoy, 2001; Lee and Chang, 2000;), was exceeded in 22 rooms $(31 \%)$. However, mold infestation appears unlikely given that indoor levels were generally lower than outdoor levels, bioaerosol compositions were similar both indoors and outdoors, humidity levels were not excessive, and no school showed evidence of water damage or other causative factors in the walkthrough inspections. Total bioaerosols were weakly but significantly negatively correlated with $\alpha$-pinene (Table 3), possibly reflecting recent or increased use of cleaning products in rooms with higher mold concentrations. Multivariate models showed that only the number of occupants $(\mathrm{STB}=0.31)$ and the presence of carpeting $(\mathrm{STB}=0.58)$ were associated with 


\section{Godwin \& Batterman}

Aspergillis concentrations $\left(R^{2}=0.19\right)$, the only bioaerosol detected in $>50 \%$ of the classrooms. Carpeting $(\mathrm{STB}=0.41)$ was the only significant predictor for total bioaerosol concentrations $\left(R^{2}=0.15\right)$. Bioaerosol concentrations in elementary and middle schools did not differ (Table 4), and within-school variability was much greater than between-school variability.

\section{Air exchange rates}

Estimated AER are listed in Table 1, and the distribution of AER is shown in Figure 1. Rates were much higher during the occupied period (average $\mathrm{AER}_{\mathrm{SS}}=$ $6.2 \pm 3.1$ per hour, $n=48$ ), as compared with late afternoon when HVAC systems are shut down to conserve energy and windows are closed (average $\mathrm{AER}_{\text {DECAY }}=0.6 \pm 0.3$ per hour, $n=47$ ). The average school-day AER $_{\text {SS }}$ in classrooms with openable windows was slightly but not statistically lower $(4.4 \pm 1.9$ per hour, $n=28)$ than rooms with fixed windows $(5.0 \pm 4.6$ per hour, $n=14, P=0.80, t$-test $)$. Possibly infrequently or only partially opened windows, and differences in the amounts of outside air provided by the HVAC system may have obscured the expected difference. However, a small but statistically significant difference was seen in the afternoon when classrooms with operable windows had a higher AER $_{\text {DECAY }}$ $(0.64 \pm 0.41$ per hour) than rooms with fixed windows $(0.38 \pm 0.27$ per hour $)(P=0.04, t$-test $)$. Rooms with operable windows may be 'leakier' than rooms with sealed or no windows, but this can only be observed when the HVAC system is off. Within-school variability for $\mathrm{AER}_{\mathrm{SS}}$ and $\mathrm{AER}_{\mathrm{DECAY}}$ was much larger than between-school variability, suggesting the importance of room effects (e.g., window and door opening).

\section{Temperature and humidity}

School-day temperatures in classrooms averaged $23 \pm 3^{\circ} \mathrm{C}$ and the $\mathrm{RH}$ averaged $38 \% \pm 9 \%$, and all but two classrooms achieved the comfort range (20 to $26^{\circ} \mathrm{C}$ and $20 \%$ to $60 \% \mathrm{RH}$ ) as per the recommendations of ASHRAE (1993). Temperatures rose steadily over the study period, averaging $14.5 \pm 9.5^{\circ} \mathrm{C}$ in April, increasing to $18.2 \pm 3.3^{\circ} \mathrm{C}$ in May, then stabilizing in mid-June to $17.3 \pm 3.6^{\circ} \mathrm{C}$. Indoor and outdoor $\mathrm{RH}$ also increased over the study period (indoors levels were $30 \% \pm 4 \%$, $39 \% \pm 6 \%$, and $43 \% \pm 6 \%$ in April, May, and June, respectively; outdoors levels were $\sim 17 \%$ higher). None of the classrooms were humidified.

\section{Discussion}

Contaminant levels

TVOC levels measured in this study fell in the range reported in previous studies. However, comparisons of
TVOC levels across studies can be problematic owing to differences in definition, measurement, and analysis (Andersson et al., 1997), and examination of specific VOC species is often more informative. Only two studies in the recent peer-reviewed literature gave concentrations of specific VOCs other than formaldehyde in schools. Shendell et al. (2004a) reported higher concentrations of benzene, toluene, and $m, p$-xylene $\left(1.7,9.5\right.$, and $2.7 \mu \mathrm{g} / \mathrm{m}^{3}$, respectively) in main building classrooms than found here, but lower levels of $\alpha$ pinene and limonene $\left(0.4\right.$ and $1.7 \mu \mathrm{g} / \mathrm{m}^{3}$, respectively; $n=3$ ), while Norback (1995) reported higher toluene and limonene concentrations (averaging 16 and $13 \mu \mathrm{g} /$ $\mathrm{m}^{3}$, respectively, $n=6$ ). Given the paucity of VOC measurements in schools, we compare concentrations in schools with those reported in office buildings. Schools have swimming pools, science and art rooms, and so on, at higher concentrations of certain VOCs (e.g., chlorinated VOCs, aromatics) might be expected. Nontheless, compared with the large BASE study of office buildings (US EPA, 2005), maximum VOC levels in schools were low with the exceptions of $\alpha$-pinene (office and classroom maxima were 8.4 and $35 \mu \mathrm{g} / \mathrm{m}^{3}$, respectively) and naphthalene (office and classroom maxima of 9.7 and $10.3 \mu \mathrm{g} / \mathrm{m}^{3}$ ).

VOCs in schools likely originated from a combination of building sources, occupant activities, and outdoor sources. We saw no clear association of VOCs with openable windows and floor area. However, the regressions were consistent in showing effects related to ventilation and the presence of carpeting, although these models provided only modest explanatory power. Excluding the model for toluene owing to its very low $R^{2}$, the standardized regression coefficients for ventilation and $\mathrm{CO}_{2}$ concentration indicated that increased ventilation was associated with decreased VOC concentrations. These results, the room-to-room variability, and the low outdoor levels suggest local (classroom) sources rather than building-wide or outdoor sources. Art and science rooms had some of the highest levels measured for certain VOCs (e.g., toluene and naphthalene, respectively). The passive sampling method provides an integrated sample for both occupied and unoccupied periods, thus, concentrations may not be representative of occupant exposure levels. Depending on the nature of the source and the ventilation, passive sampling may either over- or underestimate occupant exposures, especially for VOCs closely associated with occupant activities.

Median indoor bioaerosol concentrations were below 1000 counts per $\mathrm{m}^{3}$, which is comparable or lower to published levels measured in nonproblem buildings (Scheff et al., 2000b; Smedje and Norback, 2000). Multiple regression analyses showed concentrations of commonly detected bioaerosols were positively associated with carpeting, suggesting that carpeting 
may be a source of bioaerosols. As the measurements included both viable and nonviable particles, viable concentrations (i.e., $\mathrm{CFU} / \mathrm{m}^{3}$ ) would be lower. Unlike (Santilli, 2002) who found Alternaria, Boytrytis, Curvularia, Episoccum, and Stachybotrus exclusively indoors and at high concentrations in three 'problem schools', we found no genera that were similarly exclusive and concentrations were low. Indoor bioaerosol concentrations can be highly variable and influenced by many factors, e.g., the life cycle of the organism, season, humidity, window opening, HVAC maintenance, and air filtration. Thus, the short-term bioaerosol samples reflect concentrations only for the day the samples were taken and may not be representative of long-term exposures.

\section{Adequacy of ventilation}

Ventilation was inadequate in many of the school rooms, reinforcing earlier studies (e.g., Daisey et al., 2003; Scheff et al., 2000a; Shendell et al., 2004b). Based on $\mathrm{AER}_{\mathrm{SS}}$, only $27 \%$ of the classrooms achieved an AER of $3 / \mathrm{h}$ or more needed to achieve the ASHRAE standard of $8 \mathrm{l} / \mathrm{s}$ per person for classrooms (Daisey et al., 2003). Based on a 1000-ppm $\mathrm{CO}_{2}$ limit (ASHRAE 62-2001, 2001) and using school-day averages, $17 \%$ of the classrooms were inadequately ventilated. Ventilation in portable school rooms was notably worse than in main school buildings, also noted by Shendell et al. (2004b).

The differences found between steady-state and decay-based AER appear largely owing to differences in HVAC operation during occupied and unoccupied periods. The former were estimated for occupied periods when HVAC systems were operating, while the latter were determined when most individuals had left the building and HVAC systems were turned down or shut-off to conserve energy. The estimated steadystate AER exceed levels reported in recent studies, while the decay-based AER were comparable with the lowest values reported. For example, (Kinshella et al., 2001 ) reports a high of $3.4 / \mathrm{h}$ (range of $0.4-7.5 / \mathrm{h}$ ), while Liu et al. (2000) reports the lowest value, 0.66/h (range of $0.3-2.5 / \mathrm{h}$ ). The studied school district had recently engaged in a system-wide building and HVAC assessment and preventative maintenance program which, according to district staff, had resulted in improved operation. Seasonal differences might explain some of the results as windows and doors may have been opened more during occupied periods when the weather was warmer, near the end of the study. However, AER during occupied periods between rooms with and without operable windows were comparable. The different methods used to determine AER during occupied and unoccupied periods might explain some of the differences, though no specific biases are expected.

\section{Spatial variation}

Room-by-room variation seen for limonene, $\alpha$-pinene, bioaerosols, AERs, and $\mathrm{CO}_{2}$ suggests that differences in indoor emission sources and activities affecting pollutant levels affected measurements more than any common school factor, e.g., location, HVAC system type, and building-wide cleaning/maintenance practices. Schools contain a variety of spaces serving different activities, potentially different contaminant sources (e.g., classrooms, offices, gymnasiums, pools, art, science, wood, jewellery and metal shops, libraries, kitchens, and cafeterias), and many schools employ unitary air handlers that limit mixing with other spaces in the school. Consequently, multiple locations should be measured to characterize IAQ parameters in schools.

\section{Limitations}

The 64 classrooms in nine public school buildings sampled likely reflect IAQ and ventilation parameters in the Michigan school district; however, results may not be representative of school districts elsewhere for several reasons: (i) the tested schools were in a relatively affluent district which has active IAQ and preventative maintenance programs; (ii) schools in other climatic regimes, especially in hot and humid areas, often are dependent on air conditioning and have a greater chance of poorer ventilation, higher humidity, and mold problems; (3) the tested schools, all sited in suburban areas with generally good ambient air quality (in terms of VOCs and bioaerosols), may not reflect air quality in schools near highways, agriculture, or industry; (4) schools were monitored during the spring, a period when outdoor conditions are moderate but highly variable. Monitoring during other seasons is necessary to evaluate seasonal effects, e.g., ventilation may be further reduced during very cold and very warm seasons.

The IAQ characterizations used instruments, indicators, averaging times, and analysis methods that may differ from those used in other studies. This is especially likely for bioaerosol and VOC measurements. In contrast, $\mathrm{CO}_{2}$ measurements are generally comparable, which should improve the study comparability, though again averaging times for $\mathrm{CO}_{2}$ measurements vary. Also, monitoring did not include several potentially important contaminants (e.g., formaldehyde, particulate matter, and bacteria) and several 'microenvironments' that may provide considerable exposure, e.g., swimming pools, kitchens, and industrial arts shops. While care was taken in monitoring site placement, some measurements may not be representative, e.g., the highest $\mathrm{CO}_{2}$ concentrations might have resulted from persons breathing on the instruments. 


\section{Conclusions}

The 64 rooms monitored in nine schools in the suburban school district showed generally low levels of VOCs and bioaerosols, acceptable ranges of temperature and humidity, but often deficient rates of ventilation. The within-school variability of most IAQ parameters (most VOCs, bioaerosols, and $\mathrm{CO}_{2}$ ) was comparable with or exceeded the variability between schools, suggesting the influence of local (in-school) emissions, activities, or building features, and the need for multiple monitoring sites to characterize IAQ in schools. For VOCs, identified sources included activities in art rooms, science rooms, and indoor pools; therefore, we recommend that school buildings be designed to prevent migration of potentially contaminated air from these types of special-use areas into the rest of the building. This may be accomplished by, e.g., pressure gradients, dedicated ventilation systems, or in extreme cases standalone structures. Bioaerosols were positively associated with the presence of carpeting, suggesting that carpeting may be a source of bioaerosols in the study schools and thus should be cleaned regularly and monitored for signs of dampness and/or moisture damage. Walkthrough inspections revealed no obvious problems with HVAC systems, water damage, mold infestation, and so on, and buildings appeared to be well maintained. Nonparametric statistical methods produced very similar results to parametric methods conducted on log-transformed data.

\section{Acknowledgements}

The authors wish to thank Randy Trent and Tim Gruszczynski for their support and assistance in the field component of this study, Chunrong Jia for sample analyses, Kathy Welch for statistical assistance, and Swati Ellendula for her help with data management. This research was in part funded by a grant from the NIOSH Education and Research Center at the University of Michigan.

\section{References}

Andersson, K., Bakke, J.V., Bjørseth, O., Bornehag, C., Clausen, G., Hongslo, J.K., Kjellman, M., Kjærgaard, S., Levy, F., Mølhave, L., Skerfving, S. and Sundell, J. (1997) TVOC and health in nonindustrial indoor environments, Indoor Air, 7, 78-91.

ASHRAE (1993) ASHRAE Handbook:Fundamentals. I-P Edition (ed.) Atlanta, GA, USA, American Society of Heating, Refrigeration, and Air-Conditioning Engineers, Inc.

ASHRAE 62-2001 (2001) Ventilation for Acceptable Indoor Air Quality, Atlanta, GA, USA, American Society of Heating, Refrigeration, and Air-Conditioning Engineers, Inc.

Batterman, S., Metts, T., Kalliokoski, P. and Barnett, E. (2002) Low-flow active and passive sampling of VOCs using thermal desorption tubes: theory and application at an offset printing facility, J, Environ. Monitor., 4, 361-370.

Bush, R.K. and Portnoy, J.M. (2001) The role and abatement of fungal allergans in allergic diseases, Journal of Allergy Clin. Immunol., 107, 430-440.

Carrer, P., Bruinen de Bruin, Y., Franchi, M. and Valovirta, E. (2002) The EFA Project: Indoor air quality in European schools. In: Proceedings of the Ninth International Conference on Indoor Air Quality and Climate 2002 Vol. 2. $794-$ 799.

Daisey, J.M., Angell, W.J. and Apte, M.G. (2003) Indoor air quality, ventilation and health symptoms in schools: An analysis of existing information, Indoor Air, 13, 53-64.

GAO (1995) Conditions of America's Schools, B-259307, US General Accounting Office. GAO/HEHS-95-61, February 1.

GAO (1996) America's Schools Report Differing Conditions GAO/HEHS-96-103, $B$-260872, US General Accounting Office. June 14.

Kinshella, M.R., Van Dyke, M.V., Douglas, K.E. and Martyny, J.W. (2001) Perceptions of Indoor Air Quality Associated With Ventilation System Types in Elementary Schools, Appl. Environ. Hyg., 16, 952-960.

Liu, L.S., Krahmer, M., Fox, A., Feigley, C.E., Featherstone, A., Saraf, A. and Larsson, L. (2000) Investigation of the concentration of bacteria and their cell envelope components in indoor air in two elementary schools, J. Air Waste Manag. Assoc., 50, 1957-1967.

Lee, S.C. and Chang, M. (2000) Indoor and outdoor air quality investigation at schools in Hong Kong, Chemosphere, 41, 109-113.

Mendell, M.J. and Heath, G.A. (2004) Do indoor pollutants and thermal conditions in schools influence student performance? A critical review of the literature, Indoor Air, 15, 27-52.

NCES (2002) Overview of Public Elementary and Secondary Schools, National Center for Education Statistics, http://www.nces.ed.gov/pubs2001/overview/table06.asp. Accessed May 3, 2002.

Norback, D. (1995) Subjective indoor air quality in schools - the influence of high room temperature, carpeting, fleecy wall materials and volatile organic compounds, Indoor Air, 5, 237-246.

Peng, C.Y. and Batterman, S. (2000) Performance evaluation of a sorbent tube sampling method using short path thermal desorption for volatile organic compounds, J. Environ. Monit., 2, 313-324.

Santilli, J. (2002) Health effects of mold exposure in public schools, Curr. Allergy Asthma Rep., 2, 460-467.

Scheff, P.A., Paulius, V.K., Huang, S.W. and Conroy, L.M. (2000a) Indoor air quality in a middle school, Part I: use of $\mathrm{CO}^{2}$ as a tracer for effective ventilation, $\mathrm{Appl}$. Occup. Environ. Hyg., 15, 824-834.

Scheff, P.A.., Paulius, V.K., Curtis, L. and Conroy, L.M. (2000b) Indoor air quality in a middle school, Part II: development of Emissions Factors for Particulate Matter and Bioaerosols, Appl. Occup. Environ. Hyg., 15, 824-834.

Shendell, D.G., Winer, A.M., Stock, T.H., Zhang, L., Zhang, J., Marberti, S. and Colome, S.D. (2004a) Air concentrations of VOCs in portable and traditional classrooms: results of a pilot study in Los Angeles County. J. Exposure Analysis Environ, Epidemiol., 14, 44-59.

Shendell, D.G., Winer, A.M., Weeker, R. and Colome, S.D. (2004b) Evidence of inadequate ventilation in portable classrooms: results of a pilot study in Los Angeles County, Indoor Air, 14, 154-158.

Smedje, G. and Norback, D. (2000) New ventilation systems at select schools in Sweden - effects on asthma and exposure, 
Indoor air quality in Michigan schools

Archives of Environmental Health, Vol. 55, 1, 18-25.

US EPA (2005) Individual volatile organic compound prevalence and concentrations in 56 buildings of the building assessment survey and evaluation (BASE) study http://www.epa.gov/iaq/largebldgs/base/ images/base_2_460.pdf. Accessed September 6,2005 .
Verbeke, G. and Molenberghs, G. (2000) Linear Mixed Models for Longitudinal Data, New York, Springer-Verlag, Inc. Zar, J. (1999) Biostatistical Analysis, New Jersey, Prentice-Hall, Inc. 